https://doi.org/10.17816/MAJ191S1221-222

\title{
CALPAIN ACTIVITY UNDER EXPERIMENTAL INCREASING OF DOPAMINE LEVEL
}

\author{
N.S. Pestereval , A.Z. Marshak $^{2}$, M.N. Karpenko ${ }^{1,2}$ \\ ${ }^{1}$ Institute of Experimental Medicine, Saint Petersburg, Russia; \\ ${ }_{2}^{2}$ Peter the Great Saint Petersburg Polytechnic University, Saint Petersburg, Russia

\section{АКТИВНОСТЬ КАЛЬПАИНОВ В УСЛОВИЯХ ЭКСПЕРИМЕНТАЛЬНОГО ПОВЫШЕНИЯ УРОВНЯ ДОФАМИНА}

\author{
Н.С. Пестерева ${ }^{1}$, А.З. Маршак ${ }^{2}$, М.Н. Карпенко ${ }^{1,2}$ \\ ${ }^{1}$ ФГБНУ «Институт экспериментальной медицины», Санкт-Петербург; \\ ${ }^{2}$ ФГАОУ ВО «Санкт-Петербургский политехнический университет Петра Великого», Санкт-Петербург
}

\begin{abstract}
The aim of our study was to identify the activity of calpains under conditions of an experimental increase in the level of dopamine. The work was performed at three levels: in vivo, in situ, in vitro. An in situ study was carried on a model of isolated nerve endings - synaptosomes. Using casein zymography in solution with FITC-casein, it was shown that incubation of synaptosomes dopamine leads to calpains secretion into the synaptosomal medium. The dopamine ability to directly activate calpain was demonstrated by casein zymography in a gel. Incubation in an activation buffer containing dopamine instead of the classical activator, calcium chloride, led to the activation of calpain-2. An in vivo experiment was performed on Wistar rats. The experimental group was orally administered the drug L-dopa $(100 \mathrm{mg} / \mathrm{kg})$, the control group - saline was injected in the same way.
\end{abstract}

Keywords: calpain; dopamine; synaptosomes; nuerodegeneration; L-dope.

Целью нашего исследования было выявление активности кальпаинов в условиях экспериментального увеличении уровня дофамина. Работа была выполнена на трех уровнях: in vivo, in situ, in vitro. Исследование in situ проводилось на модели выделенных нервных окончаний - синаптосом. Методом казеиновой зимографии в растворе с использованием FITC-казеина было показано, что инкубация синаптосом с дофамином приводит к секреции кальпаинов во внесинаптосомальную среду и их активации. Способность дофамина напрямую активировать кальпаин была показана методом казеиновой зимографии в геле. Инкубация в активационном буфере, содержащем дофамин вместо классического активатора - хлорида кальция, привела к активации кальпаина-2. Эксперимент in vivo проводился на самцах крыс линии Wistar. Подопытной группе перорально вводили препарат L-dopa (100 мг/кг), контрольной - таким же способом вводили физиологический раствор.

Ключевые слова: кальпаин; дофамин; синаптосомы; нейродегенерация; Л-дофа.

Introduction. A major achievement of modern medicine is the increase in life expectancy. However, along with this, the number of patients with diagnosed neurodegenerative diseases is also growing. One of the signs of a neurodegenerative process is the calpain hyperactivation of the central nervous system (CNS) cells, for example, calpain-1 and calpain-2 [1]. Calpains are a family of calcium-dependent intracellular proteases [2]. The are 16 proteins of this family, that have been discovered to nowadays, each of which has its own tissue localization, specificity and conditions for proteolysis, both complete and limited. It was shown that the accumulation of a truncated form of $\alpha$-synuclein in cells of the CNS, leading to Parkinson's disease, is accompanied by an increased activity of calpain 1 [3]. In recent years, the theory has been strengthened that calpain-1 and calpain-2 have opposite functions in neurodegeneration/neuroprotection and in learning and memory/synaptic plasticity. The last studies have shown that calpain-1 activation is necessary for certain forms of synaptic plasticity, learning and memory, and calpain-2 is activated for a short period of consolidation the degree of plasticity/ learning decreases. Also, there is high probability that calpain-1 is neuroprotective, while calpain-2 is neurodegenerative [4].

Materials and methods. We studied the effect of the neurotransmitter dopamine on the activation of calpain-1 and calpain-2 in vitro and in vivo. The choice of this compound is due to the prevalence of Parkinson's disease (second place after Alzheimer's disease among the population). Before the manifestation of motor symptoms of the disease, more than $70 \%$ of the dopaminergic neurons of the substantia nigra to be dead. The gold standard for the treatment of Parkinson's disease is L-dopa therapy. L-dopa (dihydroxyphenylalanine) is a nutrient derived from tyrosine in the body and is a precursor of dopamine. Thereby receiving L-dopa leads to increased levels of dopamine in the CNS cells [5]. However, the effect of dopamine on calpain activity has not been previously 
studied. In this regard, the aim of our study was to identify the activity of calpains under conditions of an experimental increase in the level of dopamine. The work was performed at three levels: in vivo, in situ, in vitro. An in situ study was carried on a model of isolated nerve endings - synaptosomes. Using casein zymography in solution with FITC-casein, it was shown that incubation of synaptosomes with $5 \mathrm{mM}$ dopamine for 90 minutes leads to calpains secretion into the synaptosomal medium (Fig. 1).

The absence of bands on the caseinogram tracks shows that the entire substrate was cleaved by protease in an active form. The dopamine ability to directly activate calpain was demonstrated by casein zymography in a gel. Incubation in an activation buffer containing $2 \mathrm{mM}$ dopamine instead of the classical activator, calcium chloride $(2 \mathrm{mM})$, led to the activation of calpain-2. An in vivo experiment was performed on Wistar rats. The experimental group $(n=4)$ was orally administered the drug L-dopa $(100 \mathrm{mg} / \mathrm{kg})$, the control group $(n=4)-$ saline was injected in the same way. After 30-minute time period, decapitation was performed. By the means of HPLC, dopamine level in the sub-

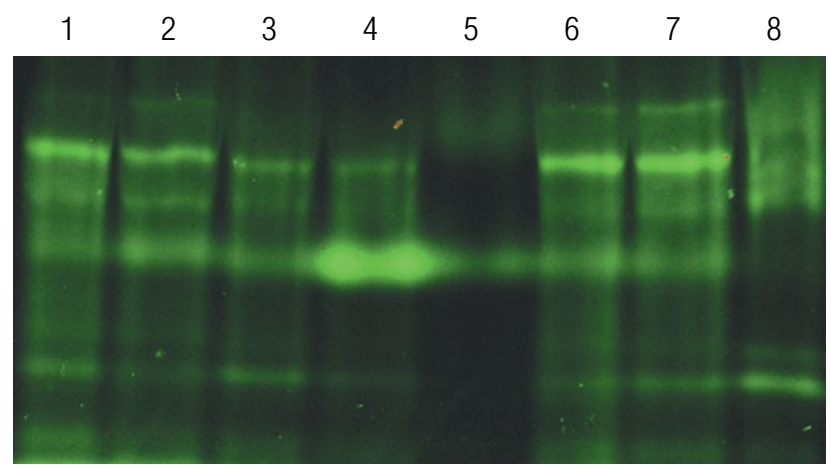

Fig. 1. Effect of Dopamine and it's metabolites on the level of calpain secretion/activation. Samples was incubated with: 1. Casein (clear), 2. EDTA $(5 \mathrm{mM}), 3 \cdot \mathrm{CaCl}_{2}(5 \mathrm{mM})$, 4. - (without adds), 5. DA $(5 \mathrm{mM})$, 6. inhibitor $+\mathrm{CaCl}_{2}$, 7. inhibitor, $8 . \mathrm{H}_{2} \mathrm{O}$ (watershock)

stantia nigra cells was found to be increased by $4.6 \pm 0.7$ times, which was a control indicator of the successful administration of 1-dopa and dopamine synthesis from it directly in the CNS cells of the animal. Interesting are the results of casein zymography in the gel. It was shown, that the introduction of L-dopa in animals leads to the suppression of the activity of calpain-1, but not of calpain-2.

\section{References}

1. Karpenko MN, Tikhomirova MS. The role of calpains in regulating synaptic transmission. Neuroscience And Behavioral Physiology. 2015; 45(8): 952-956.

2. Cheng SY, et al. Regulatory role of calpain in neuronal death. Neural Regen Res. 2018;13:556-562.

3. Schlachetzki JC, et al. Dopaminergic lesioning impairs adult hippocampal neurogenesis by distinct modification of $\alpha$-synuclein. Journal of Neuroscience Research. 2015;94:62-73.

4. Baudry M, Bi X. Calpain-1 and calpain-2: the yin and yang of synaptic plasticity and neurodegeneration. Trends Neuroscience. 2016;39:235-245.

5. Chagniel L, et al. Striatal inhibition of calpains prevents levodopa-induced neurochemical changes and abnormal involuntary movements in the hemiparkinsonian rat model. Neurobiol Dis. 2012;45:645-655. 